\title{
THE DETERMINANTS OF GLOBAL ACCOUNT MANAGEMENT (GAM). A RELATIONSHIP DECISION-MAKING MODEL
}

The article presents an analysis of the factors influencing the partnership and cooperation of companies active in the global B2B market. It outlines the benefits that are traditionally associated with joint projects or alliances and discusses to what extent they can be generated in the global customer relationship management programs on the basis of global account management (GAM). The main aim of this paper is to propose a GAM relationship decisionmaking model. Its conceptual framework is based on four assumptions dealing with the formal and informal, external and internal decision-making factors. This model can be of practical importance for globally operating suppliers in managing their relations and choosing the right customers for strategic cooperation.

Keywords: cooperation, relationship management, global account management (GAM), partnership

DOI: $10.15611 /$ aoe.2019.2.10

\section{INTRODUCTION}

Managing long-term relationships with customers, suppliers and other stakeholders has been the response of successfully competing companies for market deregulation, globalization and the intensive use of various forms of online communication tools. New organizational forms like strategic alliances (Parkhe 1993; Światowiec 2002) and networks (Gulati et al. 2000; Ratajczak-Mrozek, Małys 2012; Hauke-Lopez 2014) or innovative business models (Dymitrowski, 2016), as well as open innovation projects have emerged (Kotler 2008). The foundation of these dynamic structures is a long-term partnership which may lead to the development of a competitive advantage on a global scale.

Globalization, in particular, is transforming the world into a huge, single and virtually borderless marketplace. As part of this process, global sourcing is putting an increased pressure on suppliers to serve customers beyond their home markets (Shi et al. 2010). This new business landscape can only be

\footnotetext{
* Department of International Marketing, Poznan University of Economics and Business.
} 
mastered by adopting proper relationship management strategy and tools (Deszczyński 2018; Małys, 2017), including global account management (GAM). GAM can be defined as "an organizational form and process in multinational companies by which the worldwide activities serving a given multinational customer are coordinated centrally by one person or team within the supplying company" (Shi et al. 2010, p. 620). The first attempts of coordinated cooperation on a global scale were adopted by technology giants servicing large multinationals in the automotive, petrochemical and financial industries (Jeannet, Hennessey 2004, pp. 380-381). Nowadays examples of GAM are widespread across all industries and have also been adopted by medium-size suppliers (Yip, Bink 2007a).

Although the reasons behind the introduction of GAM may be different in a given case, some common basic goals can be outlined, including: meeting customer expectations/requirements, leveraging the effectiveness of own sales activities, offering standardization, gaining competitive edge and lowering the risk of own foreign investment (Surówka-Marszałek, Światowiec 2005). Still, a question arises of what types of accounts / relationships should be regarded as promising in the global relationship management context.

Meanwhile, despite the importance of GAM for many multinational enterprises, academic research on GAM is scarce and therefore the knowledge on GAM remains limited. In particular, there is a lack of a theoretically based integrative framework that can help in the GAM implementation decision-making process (Shi et al. 2010). The existing literature comments on GAM drivers, such as global customers, and GAM dimensions, such as types of market coordination (Montgomery et al. 1998; Swoboda et al. 2012). Some authors propose conceptual frameworks discussing GAM facilitation conditions, e.g. complementary resources, goal congruence, strategic fit (Toulan et al. 2006). Others try to embed GAM in the relationship marketing theory, explaining the shift from national account management to GAM, or the dynamic capabilities theory, explaining GAMspecific capabilities, like the coordination fit on different management levels (Shi et al. 2004; Yip, Madsen 1996). However, even if they use empirically obtained material, most of these contributions develop relatively abstract, theoretical conclusions, which do not help much in managerial decision making, especially in terms of the selection of GAM accounts. They acknowledge that, in qualifying customers for global account status, the size of their global operations cannot be the first and last criteria (Gao, Shi 2011). However, only one article published in the Harvard Business Review, comes 
with a coherent GAM decision-making model (Yip, Bink 2007a), yet for obvious reasons, it lacks theoretical grounding.

In order to bridge the gap between the theory and practice, this paper offers a "zoom-in" approach. Its main aim is to propose a GAM relationship decision-making model. Hence, it integrates the relationship marketing theory and the drivers of GAM in the form of a conceptual framework. The framework itself, however, is a workable concept. It combines formal and informal, external and internal decision-making factors to assist the management on GAM accounts' selection process based on predominately relationship management criteria. Accordingly, this paper is divided into two main sections. The first assesses the related literature streams pertaining to relationship management and GAM, while the second describes original GAM relationship decision-making model based on four assumptions. The concluding remarks differentiate the model from the other concepts, which either fragmentarily touch upon the issue of GAM accounts selection or comment on GAM as it is already implemented.

\section{THEORETICAL BACKGROUND}

\subsection{Partnership and cooperation}

There are many definitions of partnership, mainly because of the multiple types of entities constituting various forms of relations. Anderson and Narus (1999, p. 374) underline that the essence of partnership is mutually sharing the view that the success of both parties is partly interdependent and therefore joint engagement towards meeting the final market demands is beneficial for them. Such partnership creates after time strong social, economic, service and technical bonds. In turn, lowering total costs and leveraging value is achieved by common effort. An important issue of every relationship, including a business one, is the long-term perspective. Pursuing advantages like higher quality, lower costs and risk reduction should bring the balanced interdependence of partners resulting in e.g. granting preferred supplier status or even exclusive supplying contract in a given product or service category in exchange for the benefits such as special pricing or access to innovations (Frazier et al. 1988, pp. 53-54). However, not every business situation opens space for such a win-win situation (Światowiec 2001).

Figure 1 presents the factors that should be examined when assessing the prerequisites for a successful partnership. On the left side, unfavorable conditions for relationship building are shown, while on the right side the 
favorable ones, and between them spans a continuum of mixed situations. Although in general, a long-term partnership seems to be beneficial for the participating partners, some studies show successful supply chain management requires the efficient management of a portfolio of various relationships and therefore no strategy (long-term or short-term) should be taken as inherently superior (Bensaou 1999, Światowiec 2005, 2006a). According to the resource-based view, looking for partners can be perceived as seeking to improve own imperfect assets or to create new capabilities faster and at a lower cost, thus achieving competitive advantage (Czakon 2011). In some business situations (like the purchase of commodities or natural resources for further processing), a supplier may not have much more to offer than better prices, while in other cases distinctive jointly developed technology or a superior level of services may be the key for market success.

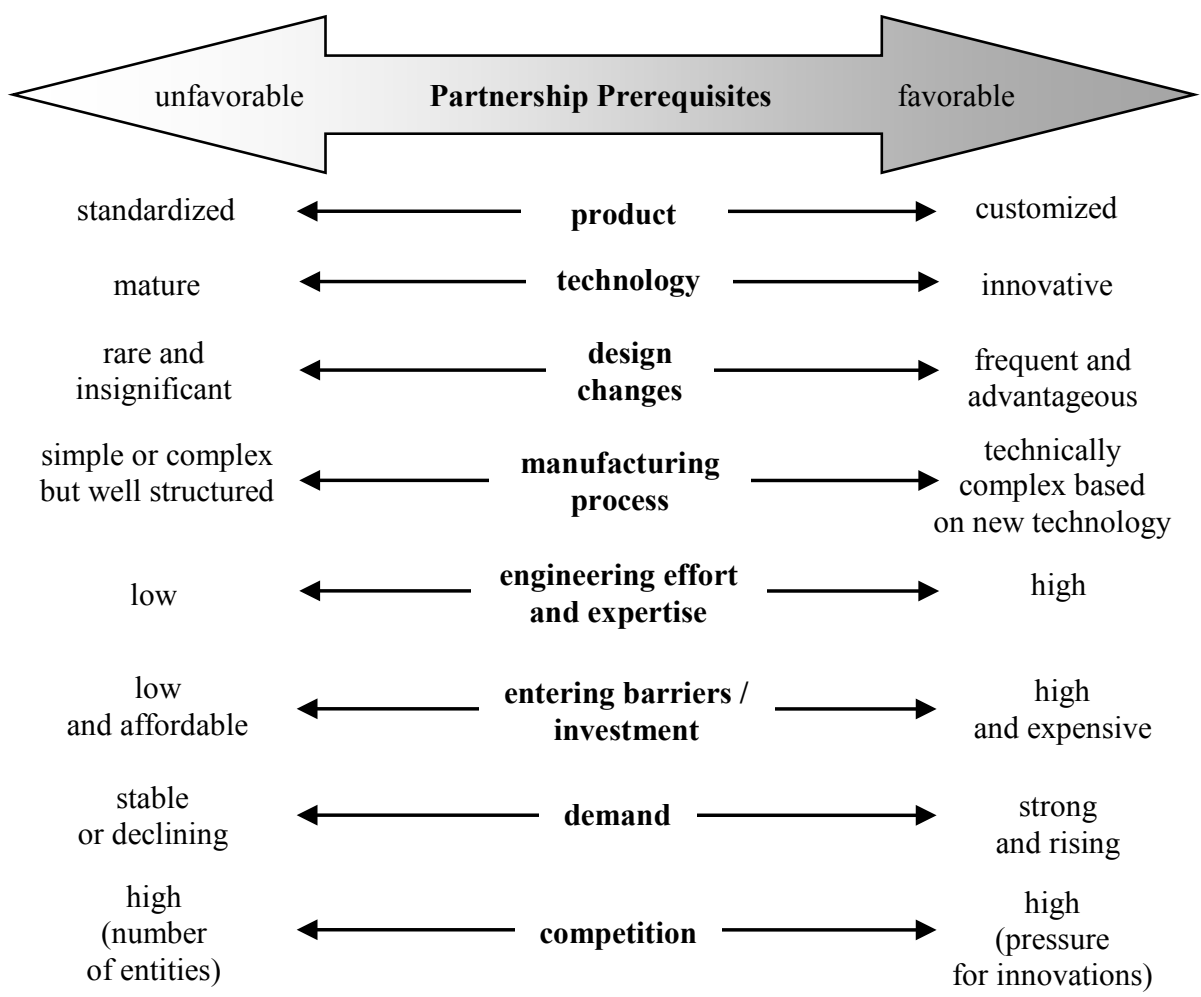

Fig. 1. Prerequisites for partnership building

Source: own work adapted from Bensaou (1999). 
Such strategic partnership owing to mutual adjustments and investment induces (as the name suggests) at least partial strategy adaptations in pursuit of a joint project, but does not exclude establishing other partnerships helpful to compete elsewhere (Sulejewicz 1997, p. 72). The prerequisites of the partnership presented in figure1 are inspired by the concept of cooperation understood as one of the key coexisting elements of market coordination (among competition and control), which is illustrated in figure 2. This framework refers to the transaction cost theory and its continuum from market to hierarchy (Williamson 1985). The diversity of ties between enterprises can constitute inter-organizational cooperation networks.

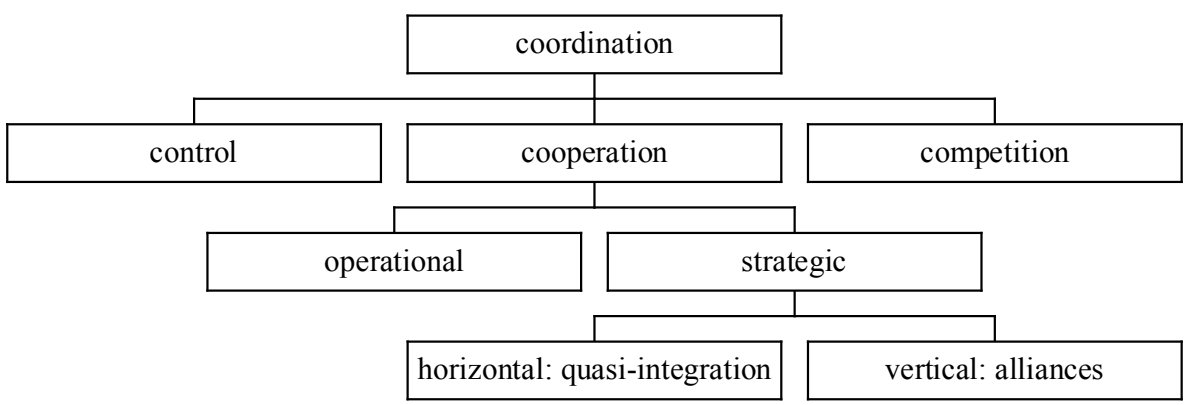

Fig. 2. Strategic partnership. CCC paradigm: control, cooperation, competition

Source: own work adapted from Sulejewicz (1997, p. 65).

Cooperation can be defined as the highly interactive process of formal and informal decision-making by independent market players (individuals, groups and organizations) in order to generate long-term benefits (Sulejewicz 1997, p. 72). According to Dwyer et al. (1987, p. 12), cooperation can also be described as complementary coordinated activities of entities staying in an interdependent relation in order to achieve goals benefiting mutual long-term expectations.

A long-term strategic partnership is therefore not a simple extension of a long-term contractual relation in which both parties maintain their bargaining positions and look for better prices or conditions. Such behavior resembles a short-term philosophy, in which buyers aim to expand their position mainly by maintaining the competition of several preferred suppliers. In turn, a long-term buyer-supplier partnership is a philosophy of trust and cooperation based on the common striving for better understanding and the creation and delivery of value for the final markets. The adoption of 
a cooperation strategy, which assumes the joint use of assets, should help in achieving the strategic competition goals (in relation to the other competitors) and facilitate mutually beneficial activities. The proportions of benefits and their consumption should stay in relation to the partners' contribution and degree of dependence, as well as the sense of fairness (Urbańczyk 2012). Therefore, it is advisable for the cooperating partners to maintain relatively comparably strong positions (Czakon 2011) in order to sustain their relation in the phase of benefits appropriation (Czakon 2009). Meanwhile, many so-called partnerships are inherently unbalanced (Birkinshaw et al. 2001). Hence, the best long-term effect of cooperation will occur if the technical and organizational competences/potential of both parties are similar in scale and scope before it starts (Movery et al. 1998, p. 510).

\subsection{Key success factors for a partnership relation}

The nature of a relation is based on mutual trust and commitment (Morgan, Hunt 1994). Trust can be perceived in two dimensions: as the credibility of the partner and as the degree of interest in the partner's success (benevolence; Ganesan 1994; Doney, Cannon 1997). Commitment means the allocation of own resources into a business venture and the partial sacrifice of individualistic aspirations. Both are irreplaceable for an effective and beneficial partnership because only these two factors combined contribute to a better business performance and strength of relation (Morgan, Hunt 1994, pp. 22-27). A model of relationship development based on trust and commitment is presented in figure 3.

Finding a business opportunity and the acceptance of roles in a possible new venture is the starting point for considering cooperation. On the contrary, looking for alternative partners as a result of a perceived downgrade of jointly generated competences, ends in the breakup of cooperation bonds.

Trust seems to be the prerequisite for entering into a new cooperation. Commitment is the result of trust both in the partner and in the joint business venture, as it starts and continues. One can distinguish two groups of factors influencing trust and commitment development: business and social factors. The first group consists of a formal assessment of the relationship in terms of:

- benefits (costs and rewards for staying in the relationship),

- capability of the partner to deliver the expected value (e.g. technical, price advantages, timing), 
- predictions of the partner's credibility and behavior in the future based on relatively impartial information.

The second group consists of:

- reputation transference of a company or/and of a sales person upon recommendations and word-of-mouth advertisement,

- perception of intentionality which is the interpretation of words, behavior, norms and values extrapolated on the sincerity of intentions,

- predictions of the partner's credibility and behavior in the future based on a subjective personal assessment.

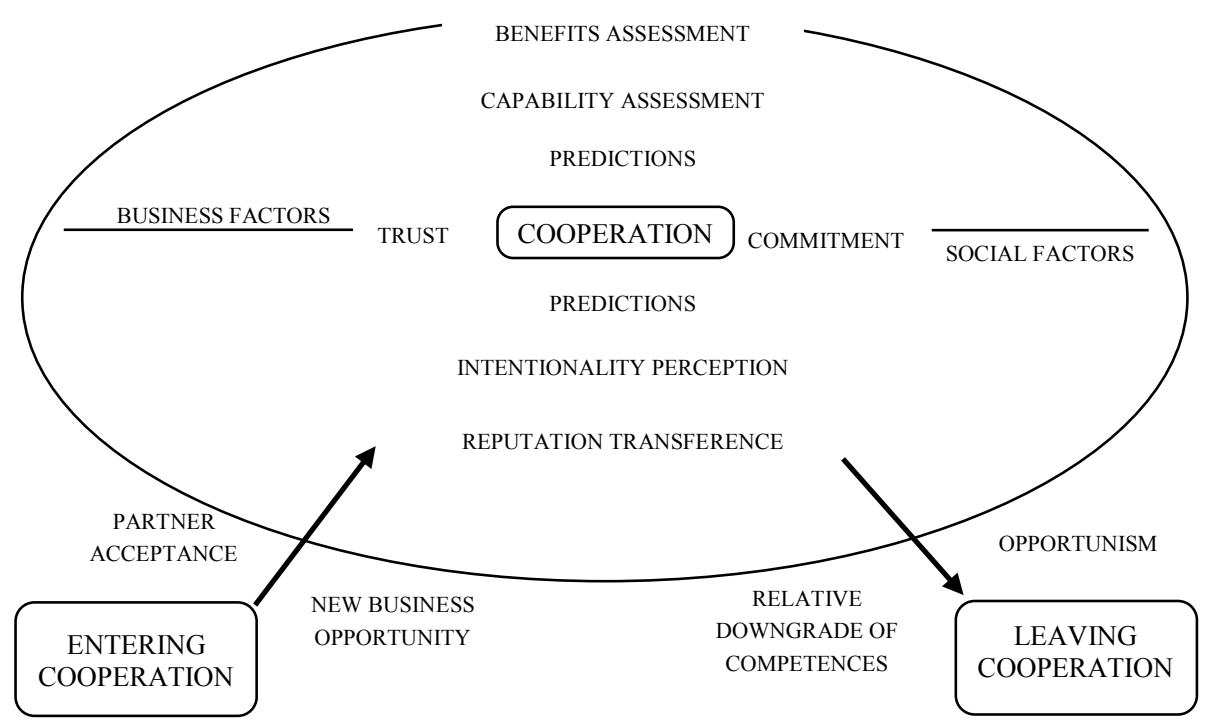

Fig. 3. Cooperation model based on trust and commitment.

Source: own work based on Doney, Cannon (1997, p. 37) and Morgan, Hunt (1994, p. 22).

The distinction between the professional evaluation of hard facts (business factors) and the individual assessment influenced by the personal experiences and preferences of respective managers seems to be substantiated both in research and practice acknowledging two levels of trust and commitment carriers: the company and its employees (Małys, Fonfara, 2018, pp. 177-178; Ratajczak-Mrozek 2017, p. 69; Bönte, Keilbach 2005 pp. 279-302, Doney, Cannon 1997). The personal attitudes of influential managers towards cooperation with a given partner can disguise some 
partner deficiencies, or vice versa may call an objectively good offer into question. Therefore, a good starting point for any investment in a future global partnership is a good mutual communication at senior executive level.

\subsection{Value creation in a relationship}

The suppliers and their sales persons in particular should actively stimulate the relation they managed to establish, by being sincere in striving for maximizing value creation for both parties and the development of mutually beneficial conditions of cooperation. Value for a business partner can be defined as the perceived surplus of benefits over costs of maintaining or developing a cooperation (Światowiec 2006b; Otto 1999). It does not have to be always a direct financial benefit but it can also be timesaving, accessing new technologies or a personal risk reduction of decision makers. In order to provide the optimal value-mix of benefits for the customers, a supplier should keep on analyzing their value creation chains and test and model processes in search for the possible gaps in the customer-centric approach. The common goal is to help the partner to compete in the final buyer market with some distinctive features making the price less important and contributing to the total customer experience, TCE (Macarenhas et al. 2006, pp. 399-400). TCE can directly benefit from product superiority or indirectly thanks to information, technological, organizational, finance or image advantages (Małys 2013, p. 38). Successful relationship development needs also the integration of training and motivation of the sales force in order to transfer the whole organization from commodity-based to valuebased selling (Deszczyński 2016).

The principles of relationship management can be introduced in organizations of any size. Because of direct access to a limited number of customers it might be even more simple and natural in small businesses. Still, owing to the potential scale of benefits, competitive pressure and capabilities of modern information technologies, customer relationship management should be in the interest of larger companies, including international and global players. In this context an obvious example of pursuing a global CRM strategy is the introduction of global account management (GAM). However, even though the extensive use of information and communication technologies is one of CRM's key characteristic (Baran, Galka 2013, pp. 5-6), the primary goal of CRM is not to install IT systems, but to optimize the value creation chain for the customers in respect to particular relationship economics. Mastering such 
a change management process is one of the most important endogenic barriers in CRM implementation (Deszczyński 2013, p. 25). In this context, GAM can be seen as a set of structures and procedures that increase the information processing capacity on a global scale. In particular, the need for understanding the global operations and goals of the customers and the demand for a better coordination among the sales and customer support units around the world have emerged as the key objective in GAM programs (Birkinhaw et al. 2001). Owing to the relationship approach this should open the door for the supplier's own value creation, as the mutual reliance and adaptation (e.g. of processes, product development strategies, investment priorities) reduce risk, costs and finally bring competitive advantage.

\subsection{Target of a Global Account Management Program}

GAM is seen as the natural extension of national account management introduced to effectively serve the most important globally operating customers. Choosing customers for global account management programs should start with the analysis of whether these buyers:

- represent a significant size and revenue potential,

- have centralized procurement activities,

- are strategically important to the supplier,

- attach the same importance to mutual contacts at top executive level.

Yip and Madsen (1996) reported that the key driver of global account programs were rapidly globalizing procurement strategies of the customers. As companies grow internationally, they seek global solutions for their business needs including one point of reference, stable prices and purchasing conditions. Individualized products and services, marketing and logistics support are among other benefits expected (Scholl 2001, pp. 1-17). In return, the supplier receives a higher priority status and possibly a bigger share of the customer's spend. Thanks to tighter cooperation, solutions for specific customer needs can be developed in mutual cooperation and/or coordination what creates an additional hurdle for other competitors. These tailored solutions can be in turn adopted as the global standard compulsory for all customer branches what may reduce the logistic effort, as well as the R\&D, manufacturing and marketing costs. The research conducted among almost 200 GAM executives from more than 150 companies showed that global account management boosts customer satisfaction by approximately 20 percent and economic results by as much as 15 percent (Montgomery, Yip 2000, pp. 22-30). 
However, some studies show that GAM does not always bring win-win partnerships. As prices become much more transparent and customers demand bigger discounts in exchange for higher volume, suppliers may lose much of their negotiating power. In addition, the cost of GAM per customer can result in hundreds of thousands of euros in extra spending for sales and support in comparison to the individual national accounts, which still remain in the national subsidiaries (Yip, Bink 2007a). Therefore, GAM cannot be perceived as a solution for every business relation and, as the whole CRM concept, it needs well thought-out decision-making, otherwise it will only add to failure rates which in the case of CRM have been traditionally high (Deszczyński, Fonfara 2014). In particular, it cannot cover up the organizational shortcomings, which only would be aggravated if trying to pursue strategies requiring an advanced coordination effort. This is reflected in a particular commercial study showing underperforming low revenue and profit organizations are 50 percent less likely to use CRM as the key driver for their success (Merkle 2013).

\section{GAM RELATIONSHIP DECISION-MAKING MODEL}

Following the literature review, four main assumptions are proposed, which constitute the foundation of the GAM relationship decision-making model, as shown in figure 4. These are:

Assumption 1: The extensive scale of operations on key domestic markets is the basic prerequisite for considering the introduction of a GAM program.

Assumption 2: The potential for mutual short-term value creation is the prerequisite for entering into GAM cooperation.

Assumption 3: The potential for mutual long-term value creation is the prerequisite for the development of GAM cooperation into a strategic partnership.

Assumption 4: The attitude towards long-term cooperation and personal relations between the top management of buyer and supplier are the ultimate condition for making tight bonds supporting GAM cooperation.

The GAM relationship decision-making process starts with a current business evaluation at national levels. If the single product/service volume is already relatively high or the customer spends liberally on the range of products/services the supplier offers as a whole (while maintaining multiple supplier policy), it is reasonable to examine their purchasing concentration. Actual or potential sales can be generated by several countries or compact 


\section{Customer advancement in global operations}

- current and potential volume,

- multi-country presence,

- significant revenue outside company's home country,

- centralized purchasing process.

\section{Mutual potential for short-term value creation}

- industry globalization as GAM driver,

- advantage in customer value due to:

- rapid offer-delivery-support processes,

- internet enabled services,

- cost effectiveness due to:

- shared services,

- $\quad$ reduced spending for marketing, logistics, IT and product variants.

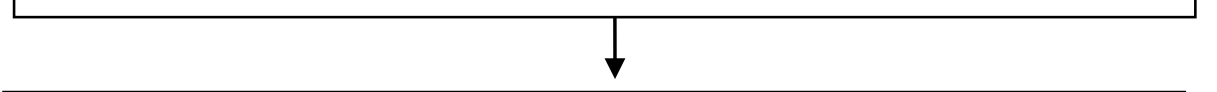

3. Mutual potential for long-term value creation through strategic cooperation

RELEVANCE

IN GLOBAL

SUPPLY CHAIN

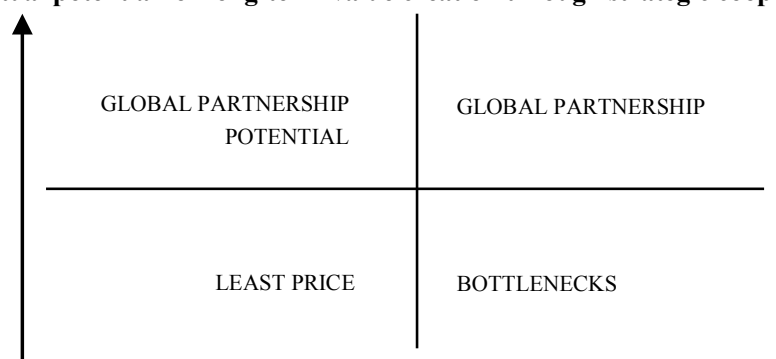

ADVANCED TECHNOLOGY / ORDER COMPLEXITY

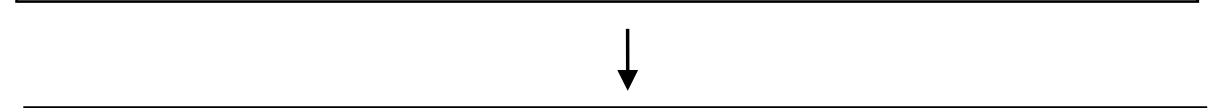

\section{Quality of partnership with a customer}

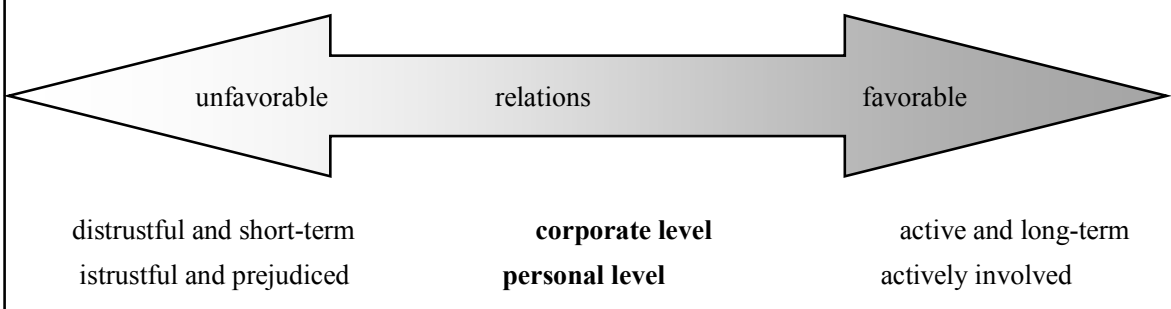

Fig. 4. GAM implementation decision-making model

Source: own work. 
geographical regions but also by a single country or region. The first situation favors further GAM implementation evaluation, while in the second it is advisable to maintain separate national account management. The substantiation for this rests in reaching a proper coordination fit between both companies (Arnold et al. 2001, p.13). Once the supplier's home country and customer's country with the strongest demand are the same, implementing GAM would only mean adding bureaucracy to the process without any chance to achieve significant results. In a mixed country situation, imposing standardization of processes upon the viewpoint of people residing far away from the key market may not only mean an additional cost in manpower and travel expenses, but could also undermine successful cooperation based on the set rules and personal contact.

The fourth factor in step 1 of the model is beyond the influence of the supplier. In fact, there is an increasing pressure on suppliers to serve the global customers beyond their home markets (Shi et al. 2010, p. 620). If their partners decided to move towards global sourcing or seek global alliance possibilities, there may not be any other way than to globalize account management or cease cooperation with such buyers.

In the following steps two, three and four of the decision-making process, the details of different levels of fit (alignment) between the buyer and the supplier are discussed. These are the operational, strategic and personal fit (Richards, Jones 2009, p. 314). In the second step of the evaluation the supplier has a pre-qualified group of customers who are candidates for the new partnership organization. However, in order to avoid a situation where the pressure for deeper discounts is the only effect of a global cooperation, the supplier has to examine the room for the short-term internal optimization based on customer value creation and cost effectiveness. Globally purchasing companies would benefit from consistency in the selection and qualification of new tools, prefabricated elements or set routines for services and thereby reducing time and cost for implementing changes in production facilities or processes worldwide. Hence the supplier has to maximize the ability to unlock its competence hidden in the people, processes and systems across the whole organization. For instance, informal platform for sharing experiences or/and formal best practices and knowledge management programs combined with GAM, should lead to a better performance in meeting the customer needs by instantly assisting their processes anywhere in the world on the basis of the pioneering country or even a single manufacturing location (Given, Smith 2014). In addition, establishing webbased services including e-communities should provide the client's local 
managers with valuable knowledge concerning product performance and implementation, relevant articles, problem-solving oriented discussions, enews and other useful data. Thus good experiences in one plant or office can help in getting a positive cooperation climate in other locations of the same customer (Bradford, Atkinson 2014). This can be extremely successful not just for the big corporations which have had GAM organizations for years but also for medium-sized companies.

Proficiency in customer care can also open the way for cost reductions thanks to the centralization of customer support centers: implementation of Shared Services Centers - SSC (Radło 2013, pp. 215-220). It also maximizes the likelihood of selling to all or almost all of the customer's locations. Other benefits include: cost reductions in spending for marketing, logistics, IT as well as product variants development. However, significant effort is needed to overcome potential organizational immaturity hindering effective cooperation in matrix management environment, sticking to global priorities and maintaining one-face-to-the-customer. As was already stated, a GAM strategic selling model as the whole CRM strategy is not a magic solution for underperforming companies, but a powerful tool for industrial leaders successfully managing their people and processes.

The scale of potential business and its internal capability to contribute to current customer processes may not be sufficient to develop long-term beneficial relation. First, the industry the supplier is operating in may be both extremely competitive and lacking significant advancements in the technology. Such an unfavorable situation exists in most of the commodities' industries, where price is a dominant purchasing driver. Second, the products / services the supplier is offering may play a minor role in the customer value chain. The supplier may, therefore, lack the potential to effectively contribute to the buyer's market success. Consequently, the buying company will not pay much attention to a particular supplier and will possibly leave such purchases in the hands of the line employees or will introduce a price bidding platform.

Both situations represent the lower left corner of the graph shown in figure 4 (step 3) and constitute unfavorable conditions to relation development and thus for GAM introduction, because of the low or the absence of strategic fit of both companies (Toulan et al. 2006, pp. 67-68). In the lower right corner the chances for long-lasting relationship building are still not present, even if, due to advanced technology or order complexity, the customer cannot expect to find a number of suppliers trumping their prices. Owing to the relatively short period of one-time interest a customer 
has on offer, the supplier is needed as a specialist for concrete problem solving. Once this is done, no ongoing business remains to fuel the relationship. In addition, it seems such bottlenecks are rather caused locally (e.g. investment in a new manufacturing line/facility) and therefore they build no potential to set up a GAM organization.

More favorable conditions for the development of a partnership are present if, admittedly, the supplier industry is not technologically advanced, but their products / services play a significant role in the particular business strategy of their customers. Consequently, the customer's interest in cooperation with the chosen supplier tends to be higher e.g. because of the demand for risk reduction and process compatibility. One such example comes from the global shipping industry, where customers have been traditionally making choices between more or less expensive transportation space. Meanwhile Maersk (the globally operating Danish company) realized that for some companies who follow the just-in-time principle, marine transport is a major problem. Thanks to increased timeliness and reliability, Maersk improved the value chain of its best customers and transformed from a commodity-based to a value-based supplier which resulted in $350 \% \mathrm{ROI}$ in less than a year (Levit 2014).

The best premises for a long-lasting mutually beneficial relationship exist if both factors shown in figure 5 (step 3 ) reach their highest magnitude. The importance in the value creation chain is a prerequisite for the openness for tighter cooperation, while technological advancement and complexity makes the supplier more attractive for today's business and reduces the pool of alternative partners in the future. It also connects the prospects of both entities in the development of even more advanced solutions raising the competitiveness of the buyer in the end-market and thus securing the position of the supplier.

The essence of cooperating on a global scale is, therefore, the creation and delivery of a specific added value. This value tends to become higher with time, as the relation develops and joint projects start. To fuel the relation such jointly developed value should be calculable and superior to other alternatives. Research comprising 58 global companies shows that they tend to pay more for four value categories: process, cost reducing administration services, individualized marketing and sales support with advanced technology on top (NAM/GAM 1997). In order to meet such expectations both parties have to actively participate in a three-stage process:

- setting the goals of global cooperation,

- adjusting business processes, 
- establishing knowledge management and implementation of learning organization principles in the network organization.

However, even if all factors listed in figure 5 (steps 1 to 3 ) are favorable for long-term cooperation, there exists the final fourth step of GAM evaluation which may mix up the results of such calculations.

Customer willingness to cooperate with the supplier on an extensive global scale is not only influenced by a formal strategy but also by informal, personal contacts and the preferences of top managers from both parties the personal fit (Shi et al. 2005). These can tip the balance for making a particular decision, especially if other considered options seem to be comparable (Deszczyński et al. 2017). The managerial decision-making often relies on habits of the mind and intuition, especially if positive moods are associated with the subject of the decision (Dane, Pratt 2007, pp. 47-48). Thus individual likings (of people or even places) can heavily influence decisions for developing tighter relations with the supplier as they are grounded in the motivational and cognitive predispositions of individuals to achieve congruency in a relationship. This congruency relies on three factors: degree of uncertainty assembled with maintaining relations, the extent of interpersonal trust and the definition of the expectations of the partnership in terms of efficiency and equity (Ring, Van de Ven 1994, pp. 95-99). Moreover, relative advantage in access to information over an often dispersed group of owners enables top management to effectively include in the corporate decision-making process their own interests of power, prestige, security as well as likes and dislikes (Noga 2009, pp. 192195; Gorynia 1998, pp. 22-24). All this makes the relationship development process a more complex issue, however it gives an opportunity to use this informal factor to successfully overcome difficulties that would normally make GAM implementation unfeasible.

\section{CONCLUSIONS}

The literature review on GAM as a distinct relationship management program indicates that a long-term partnership and cooperation offer great potential for the supplying companies active in the B2B market. However, it also shows that creating value in a global relationship on the premise of economies of scale only, can produce significant losses for the supplier in terms of margin and profits. Thus GAM can fail to improve the economics of a relationship even if loyalty - commonly linked with profitability - is in 
place, and thus, from the supplier's perspective, the implementation of GAM is frequently problematic. This requires coordination within the central corporate functions and across national borders. This creates some important marketing challenges and it can be counterproductive if the pressure on the price turns out to be its only tangible effect. It seems, therefore, that the implementation of GAM requires a certain degree of buyer-supplier alignment and a corporate relationship management maturity.

The effect of the conceptual work presented in this paper is the gradual model of GAM relationship decision-making process based on the theory of relationship management, and global account management in particular. It simultaneously shows the fields of potential value creation and the restrictions for companies considering introduction GAM. The model aims at integrating all the important issues in GAM decision-making, which are either fragmented in the other frameworks or distilled to such an abstract level that they cannot serve as a managerial tool (Hollensen, Wulff 2010; Shi et al. 2010; Yip, Madsen 1996).

Its first step starts with the traditional sales volume analysis. The second step aims at looking for short-term opportunities to meet the buyer's expectations in terms of creating qualitative added value as well as cost reductions in more areas than manufacturing only. The third step is oriented on matching the relevance and technological advancement of the supplier and the buyer in order to form the basis for a more intensive and long-lasting strategic cooperation. The second and the third steps combined comprise an integrated approach, which is barely seen in the literature. Most of the authors place emphasis only on the strategic cooperation (Toulan et al. 2006) or merely briefly comment on the need for the immediate positive results of GAM (Harvey et al. 2003). Meanwhile, without significant short-term benefits, there will be no chance to further develop the relationship. The final step emphasizes the importance of the attitudes which influence the factual customer interest in the long-term cooperation including the informal relations and the personal choices of top management. This issue has been also largely overlooked in the GAM literature with the exception of Toulan et al. (2006) and Wilson, Weilbaker (2004).

If the criteria of choice of potential GAM partners predominately based on the relationship approach proposed in this model significantly correlate with the mutual value creation for both supplier and buyer and the longevity of their cooperation, this should be examined further in the field research. Due to the interdependencies of formal external and internal factors as well as informal individual managerial choices, such research would require 
longitudinal observation and the application of extensive interviewing techniques. Still, the zoom-in approach proposed in this model seems to be close to the reality of business logic and therefore can already be of help for the decision makers in globally operating B2B suppliers.

\section{REFERENCES}

Anderson, J. C., Narus, J. A., Business Market Management. Understanding, Creating, and Delivering Value. Prentice Hall, New Jersey 1999.

Arnold, D., Birkinshaw, J., Toulan, O., Can selling be globalized? The pitfalls of global account management, "California Management Review', 44, 1, pp. 8-20, 2001.

Baran, R. J., Galka, R. J., CRM. The Foundation of Contemporary Marketing Strategy. Routledge, New York 2013.

Bensaou, B., Not by partnerships alone: Managing a portfolio of relationships, "Sloan Management Review", 40, 4, pp. 35-44, 1999.

Birkinshaw, J. M., Toulan O., Arnold, D., Global account management in multinational corporations: theory and evidence, "Journal of International Business Studies", 32, 2, pp. 321-348, 2001.

Bönte, W., Keilbach, M., Concubinage or marriage? Informal and formal cooperation for innovation, "International Journal of Industrial Organization", 23, 3-4, pp. 279-302, 2005.

Bradford, E., Atkinson, D., Case study: Global facilities management: Revitalizing and relaunching KAM in tough times, http://www.fourpillars.co/case-study-global-facilitiesmanagement-revitalizing-and-re-launching-kam-in-tough-times/ (25.07.2014).

Czakon, W., Koopetycja - splot tworzenia i zawtaszczania wartości [Coopetition - a cross between value creation and exploitation], "Przegląd Organizacji”, 12, pp. 11-14, 2009.

Czakon, W., Paradygmat sieciowy w naukach o zarzadzaniu [Network paradigm in management science], „Przegląd Organizacji”, 11, 5, pp. 1-9, 2011.

Dane, E., Pratt, M. G., Exploring intuition and its role in managerial decision-making. "Academy of Management Review", 32, 1, pp. 33-54, 2007.

Deszczyński, B., Lead management jako źródto short-term wins $w$ procesie zarzadzania relacjami z klientami [Lead management as a source of short-term wins in customer relationship management], "Marketing i Rynek", 5, pp. 24-32, 2013.

Deszczyński, B., The maturity of corporate relationship management, "Gospodarka Narodowa", 3, 283, pp. 73-104, 2016.

Deszczyński, B., The integrated relationship management framework, "Ekonomia i Prawo", 17, 1, pp. 17-31, 2018.

Deszczyński, B., Fonfara, K., Marketing partnerski (relationship marketing) na rynku międzynarodowym [Relationship marketing in international market], [in:] Fonfara, K. (ed.) Marketing międzynarodowy. Wspótczesne trendy i praktyka [International marketing. Contemporary trends and business practice]. Wydawnictwo PWN, Warsaw 2014.

Deszczyński, B., Fonfara, K., Dymitrowski, A., The role of relationships in initiating the internationalisation process in B2B markets, "Entrepreneurial Business and Economics Review", 5, 4, pp. 91-109, 2017. 
Doney, P. M., Cannon, J. P., An examination of trust in buyer-seller relationships, "Journal of Marketing", 61, 2, pp. 35-51, 1997.

Dwyer, R., Schurr, P., Oh, S., Developing buyer-seller relationships, “Journal of Marketing”, 51, pp. 11-27, 1987.

Dymitrowski, A., The nature of business model innovation, [in:] Borusiak, B., Lewicki, M. (eds.), Innovation Management: Research Aspects, pp. 19-28. Bogucki Wydawnictwo Naukowe, Poznan 2016.

Frazier, G. L., Spekman, R. E., O'Neal, Ch. R., Just-in-time exchange relationships in industrial markets, "Journal of Marketing", 52, pp. 52-67, 1988.

Ganesan, S., Determinants of long-term orientation in buyer-seller relationship, "Journal of Marketing", 58, pp. 1-19, 1994.

Gao, T., Shi, L. H., How do multinational suppliers formulate mechanisms of global account coordination? An integrative framework and empirical study, "Journal of International Marketing”, 19, 4, pp. 61-87, 2011.

Given, L. L., Smith, Ch. R., Global account management, strategic selling tool for the $21^{\text {st }}$ century, http://www.questteam.com/resources/article.html?id=given_smith_article_1, (25.08.2014).

Gorynia, M., Zachowania przedsiębiorstw w okresie transformacji. Mikroekonomia przejścia [Enterprise behavior during the time of transition. Microeconomics of change]. Wydawnictwo Akademii Ekonomicznej w Poznaniu, Poznań 1998.

Gulati, R., Nohria, N., Zaheer, A., Strategic networks, "Strategic Management Journal”, 21, 3, pp. 203-215, 2000.

Harvey, M., Myers, M. B., Novicevic, M. M., The managerial issues associated with global account management: A relational contract perspective, "Journal of Management Development", 22, 2, pp. 103-129, 2003.

Hollensen, S., Wulff, V. S. Global account management (GAM): Creating companywide and worldwide relationships to global customers, "International Journal of Customer Relationship Marketing and Management”, 1, 1, pp. 28-47, 2010.

Hauke-Lopes, A. Kluczowe wyzwania dla lidera strategicznej sieci biznesowej działajacej na zagranicznym rynku ustug [Key challenges for the leader of a strategic business network active in an international services market], "Studia Oeconomica Posnaniensia", 2, 1, pp.7-26, 2014.

Jeannet, J.-P., Hennessey, H. D., Global marketing strategies, Sixth Edition, Houghton Mifflin Company, Boston 2004.

Kotler, Ph., Lecture on marketing strategy at London Business Forum on 22 $2^{\text {nd }}$ of May 2008.

Levit, A., How to sell value instead of commodities, http:/www.forbes.com/sites/ theyec/2013/08/08/how-to-sell-value-instead-of-commodities (26.08.2014).

Macarenhas, O. A., Kesavan, R., Bernacchi, M., Lasting customer loyalty; a total customer experience approach, "Journal of Consumer Marketing”, 23, 7, pp. 397-405, 2006.

Małys, Ł., Siła powiazań sieciowych w procesie internacjonalizacji a wyniki przedsiębiorstwa [The strength of network relations in the internationalization process and the performance of the company], Difin, Warsaw 2013. 
Małys, Ł., Sieci biznesowe a kultura organizacyjna [Business networks and corporate culture], "Marketing i Rynek", 9, pp. 217-222, 2017.

Małys, Ł., Fonfara, K., The types of trust in the development process of the international business relationships: An exploratory study among Polish companies, "Entrepreneurial Business and Economics Review", 6, 3, pp. 175-191, 2018.

Merkle Group Inc., CRM survey, http://www.dmnews.com/63-of-crm-initiatives-fail/article/ 303470/ (31.10.2014).

Montgomery, D. B., Yip, G. S., The challenge of global customer management, "Marketing Management", 9, 4, p. 22, 2000.

Montgomery, D. B., Yip, G. S., Villalonga, B., The use and performance effect of global account management: An empirical analysis using structural equations modeling. Graduate School of Business, Stanford University, 1998.

Morgan, R. M, Hunt, S. D., The commitment-trust theory of relationship marketing, "Journal of Marketing", 58, pp. 20-38, 1994.

Movery, D. C., Oxley, J. E., Silverman, B. S., Technological overlap and interfirm cooperation: Implications for the resource-based view of the firm, "Research Policy", 27, 5, pp. 507-523, 1998.

NAM/GAM. Benchmark consortium: National account benchmarking, Chicago Il.: National Account Management Association and HR Chally Group Consortium, October 1997.

Noga, A., Teorie przedsiębiorstw [The theories of an enterprise], PWE, Warszawa 2009.

Otto, J., Zadowolenie klienta $i$ wartość dla klienta [Customer satisfaction and value for the customer], "Marketing i Rynek", 6, 12, 1999.

Parkhe, A., Strategic alliance structuring: A game theoretic and transaction cost examination of interfirm cooperation. "Academy of Management Journal”, 36, 4, pp. 794-829, 1993.

Radło, M.-J., Offshoring i outsourcing. Implikacje dla gospodarki i przedsiębiorstw [Offshoring and outsourcng. The implications for the economy and business], Szkoła Główna Handlowa, Oficyna Wydawnicza, Warsaw 2013.

Ratajczak-Mrozek, M., Network embeddedness. Examining the effect on business performance and internationalization, Palgrave Macmillan, Cham, Switzerland, 2017.

Ratajczak-Mrozek, M., Małys, Ł., Supply chain cooperation and company performance, "Argumenta Oeconomica", 2, 29, pp. 89-107, 2012.

Richards, K. A., Jones, E., Key account management: Adding elements of account fit to an integrative theoretical framework, "Journal of Personal Selling \& Sales Management", 29, 4, pp. 305-320, 2009.

Ring, P. S., Van de Ven, A. H., Developmental process of cooperative interorganizational relationships, “Academy of Management Review", 19, 1, pp. 90-118, 1994.

Scholl, S., International customer management at $P \& G$, Brussels: A.T. Kearney; SAMA European Forum 2001.

Shi, L. H., White, J., Zou, S., Cavusgil, S. T., Global account management strategies: Drivers and outcomes, "Journal of International Business Studies", 41, 4, pp. 620-638, 2010.

Shi, L. H., Zou S., Cavusgil, S. T., A conceptual framework of global account management capabilities and firm performance, "International Business Review", 13, 5, pp. 539-553, 2004. 
Shi, L. H., Zou S., White, J. C., McNally, R. C., Cavusgil, S. T., Executive insights: Global account management capability: Insights from leading suppliers. "Journal of International Marketing", 13, 2, pp. 93-113, 2005.

Simon, H., Zarzadzanie cenami [Price management]. PWN, Warsaw 1996.

Sulejewicz, A., Partnerstwo strategiczne: Modelowanie wspótpracy przedsiębiorstw [Strategic partnership, the modelling of cooperation among companies], „Monografie i Opracowania" 427. Szkoła Główna Handlowa, Warsaw 1997.

Surówka-Marszałek, D., Światowiec, J., Zarządzanie klientem globalnym [Global customer management] [in:] Wiktor, J. W. (ed.), Euromarketing. Strategie przedsiębiorstw ma rynku europejskim, V Sympozjum Marketingu Międzynarodowego [Euromarketing. Business strategies in the European market, 5th Symphosium of international marketing]. Akademia Ekonomiczna w Krakowie, Cracow 2005.

Swoboda, B., Schlüter, A., Olejnik, E., Morschett, D. Does centralising global account management activities in response to international retailers pay off?, "Management International Review", 52, 5, pp. 727-756, 2012.

Światowiec, J., Determinanty rozwoju więzi dlugookresowych między dostawca a nabywca na rynku dóbr przemystowych [The determinants of long-term relations between the supplier and buyer in the commodities market], "Marketing i Rynek", 1, 2001.

Światowiec, J., Partnerstwo $w$ relacjach dostawca-nabywca na rynkach przemystowych [Partnership in supplier-buyer relationships in the B2B markets], "Świat Marketingu", 2002, http://www.swiatmarketingu.pl/index.php?rodzaj=01\&id_numer=797274 (2015.10.31).

Światowiec, J., Koegzystencja marketingu partnerskiego i transakcyjnego [The coexistence of relationship and transaction marketing] [in:] Innowacje w marketingu. Młodzi o marketingu III [Marketing innovations. The youth about marketing, 3rd edition], Uniwersytet Gdański, Instytut Handlu Zagranicznego, Zakład Marketingu, Sopot 2005.

Światowiec, J., Optymalizacja portfela klientów na rynku przedsiębiorstw [Customer portfolio optimization in the B2B market] [in:] „Prawo, zarządzanie, marketing” 2005-2006. Wydawnictwo Wyższej Szkoły Handlowej w Krakowie, 2006a.

Światowiec, J., Koncepcja wartości jako podstawa wspótpracy przedsiębiorstw [The concept of value as the foundation for cooperation in business], „Przegląd Organizacji”, 4, pp. 3437, 2006b.

Toulan, O., Birkinshaw, J., Arnold, D., The Role of Interorganizational Fit in Global Account Management, "International Studies of Management \& Organization", Vol. 36, No 4, pp. 61-81, 2006.

Urbańczyk, T., Poczucie sprawiedliwości w związkach wewnatrz lańcucha dostaw: Rozwój sieci dostaw poprzez wdrażanie koncepcji lańcucha solidarności [The feeling of justice in the supply chain: The development of supply network by the implementation of the chain of solidarity concept] - PhD thesis, Uniwersytet Ekonomiczny w Poznaniu, 2012.

Williamson, O. E., The Economic Institutions of Capitalism: Firms, Markets,. Relational Contracting, Free Press, New York 1985.

Wilson, K., Weilbaker, D., Global account management: A literature based conceptual model, "American Journal of Business", 19, 1, pp. 15-22, 2004. 
Yip, G. S., Strategia globalna [Global strategy]. PWE, Warsaw 2004.

Yip, G. S., Bink, A. J. M., Managing Global Accounts, "Harvard Business Review", September $2007 \mathrm{a}$.

Yip, G. S., Bink, A. J. M., Managing Global Account, An Integrated Approach, Oxford University Press, Oxford 2007b.

Yip, G. S., Madsen, T. L., Global account management: The new frontier in relationship marketing, "International Marketing Review", 13, 3, pp.24-42, 1996.

Received: May 2016, revised: February 2019

Acknowledgement: This article was prepared as a result of research project 2015/19/ D/HS4/01956 funded by the Polish National Science Centre. 